\title{
The characterization of physicochemical, microbiological and sensorial red ginger yogurt during fermentation
}

\author{
1,3, ${ }^{*}$ Widayat, ${ }^{1}$ Satriadi, H., ${ }^{2}$ Cahyono, B., ${ }^{1}$ Girsang, D., ${ }^{1}$ Prabandari, N. and ${ }^{3}$ Dita, A.S. \\ ${ }^{I}$ Department of Chemical Engineering, Faculty of Engineering, Diponegoro University, Jl. Prof Soedarto \\ SH Tembalang, Semarang 50239 \\ ${ }^{2}$ Department of Chemistry, Faculty of Science and Mathematics, Diponegoro University, Jl. Prof Soedarto \\ SH Tembalang, Semarang, 50239 \\ ${ }^{3}$ Integrated Laboratory of Diponegoro University, Jl. Prof Soedarto SH Tembalang, Semarang, 50239
}

\author{
Article history: \\ Received: 20 March 2020 \\ Received in revised form: 17 \\ May 2020 \\ Accepted: 31 May 2020 \\ Available Online: 29 June \\ 2020
}

Keywords:

Red ginger,

Yogurt,

Lactic acid bacteria,

Fermentation

\section{DOI:}

https://doi.org/10.26656/fr.2017.4(5).127

\begin{abstract}
This study was aimed to determine the effect of red ginger extract concentration (0.2, 0.4, $0.6,0.8,1 \% v / v)$ and fermentation time on the quality and acidity of yogurt. Yogurt was made from fresh cow milk, Lactobacillus bulgaricus and 2\% v/v Streptococcus thermophilus. Operation conditions included fermentation time of $60 \mathrm{hrs}$ and data retrieval every $12 \mathrm{hrs}$. The results of this study had shown that $\mathrm{pH}$ of yogurt was decreasing, while titratable acidity increased during the fermentation time. The addition of red ginger extract did not give a significant effect on the protein content of yogurt. Yogurt with higher concentration of ginger extract increased the spicy aroma and flavor, however its color was similar to the commercial yogurt. At higher concentrations, red ginger displayed antimicrobial and antifungal characteristics, as shown by the decreasing microorganisms counts.
\end{abstract}

\section{Introduction}

Yogurt is a fermented milk product consumed widely worldwide. It could be made from homogenized milk, low-fat milk or skimmed milk (Abubakar et al., 1998; Baba et al., 2018). During the fermentation process, lactose in milk is converted to lactic acid by lactic acid bacteria Streptococcus thermophilus and Lactobacillus bulgaricus (Amadou et al., 2018). Furthermore, sugars in milk are also hydrolyzed by those bacteria, resulting in conversion of lactose to lactic acid. Meanwhile, $S$. thermophilus is responsible for its flavor (Adolfsson et al., 2004; Tamime and Marshall, 2007). Yogurt contains protein, probiotics, minerals and vitamins that are essential for the human body (Buttris, 1997; Ihemeje et al., 2015). Perdigeon et al. (1998) stated that yogurt consumption promotes good health, including reduces the risk of intestinal disease and promotes gut health. Heymans (2000) and Leblanc and Pedrigon (2004) also supported the study further by concluding that yogurt also lowers cholesterol levels in the blood, increases body immunity and assists in protein, calcium and iron assimilation.

The quality of yogurt depends on its physicochemical, microbiological and sensorial characteristics (Yang et al., 2012). Natural flavors (commonly fruits) are preferable compared to synthetic ones as it further increases the health benefits of consuming yogurt. Fruit and yogurt have been identified individually as indicators of healthy dietary patterns. Fruits are relatively low in energy density and are an excellent source of antioxidants and prebiotic fibers and polyphenols, which can promote digestive health. Combining the intake of yogurt and fruit could provide probiotics, prebiotics, high-quality protein, important fatty acids, and a mixture of vitamins and minerals that have the potential to exert synergistic effects on health (Fernandez, 2017). One potential natural flavor is red ginger (Zingiber officinale var rubrum) which is commonly used as a natural flavoring agent in the food industry and also as a bioactive component in the pharmaceutical industry (Tajkarimi, 2010; Rajathi et al., 2017). Red ginger is famous for its antimicrobial, antifungal and antioxidant capabilities (Srivastava et al., 2015) which could help delay the degradation in yogurt. This study aims to investigate the effect of varying concentration on red ginger extract addition and fermentation time on yogurt characteristics. 


\section{Materials and methods}

\subsection{Materials}

Fresh cow milk and red ginger obtained from the local market in Semarang, Indonesia. Chemicals used were L. bulgaricus and S. thermophilus fermentation starters (Merck, Germany), $\mathrm{NaOH}$ (97\%, Merck, Germany), formaldehyde solution (37\%, Merck, Germany), potassium oxalate monohydrate (99.9\%, Merck, Germany) and phenolphthalein (Merck, Germany).

\subsection{Characterization of fresh cow milk}

Fresh cow milk was organoleptically tested to determine the taste, smell and color. The $\mathrm{pH}$ value of fresh cow milk was determined using a digital $\mathrm{pH}$ meter. The $\mathrm{pH}$ meter was firstly calibrated at $\mathrm{pH} 4$ and 10 with buffer standards solution. Milk as much as $50 \mathrm{~mL}$ was then placed in a beaker, the calibrated $\mathrm{pH}$ meter was then inserted and the obtained $\mathrm{pH}$ value was recorded. Viscosity was measured using a Brookfield viscometer (Brookfield DVII, USA) with spindle no.4 and $3 \mathrm{rpm}$ rotation speed, results recorded in centipoise $(\mathrm{cP})$ after 60 seconds of shearing. The density of milk was measured using pycnometer $25 \mathrm{~mL}$ (IWAKI pyrex). Protein and fat contents of the milk were also investigated for further characterization.

\subsection{Characterization of red ginger extract}

Grated red ginger was hand-squeezed to obtain its extract. The extract was organoleptically tested for its taste, odor and color. Further characterization included moisture and ash content tests.

\subsection{Yogurt preparation}

Yogurt was prepared by heating fresh cow milk to $70^{\circ} \mathrm{C}$ and later cooled to $25^{\circ} \mathrm{C}$. The milk was added with red ginger extract of varying concentrations $(0.2,0.4$, $0.6,0.8,1 \% v / v)$ and $2 \% v / v$ fermentation starters. Anaerobic fermentation took place to form yogurt for 60 hrs. The fermentation was carried out in sterilized reactor.

\subsection{Characterization of yogurt product}

The product was characterized for its $\mathrm{pH}$, density, titratable acidity value, protein content and lactic acid bacteria count. $\mathrm{pH}$ and density were measured using $\mathrm{pH}$ meter and pycnometer respectively. The titratable acid (TA) of yogurt was analyzed by diluting $10 \mathrm{~g}$ of yogurt with $10 \mathrm{~mL}$ of distilled water, then titrating by $0.1 \mathrm{~N}$ $\mathrm{NaOH}$ solution and methyl red as an endpoint indicator (Krisnaningsih et al., 2019). Titratable acidity value was calculated using the following equation:

Titratable Acidity $\equiv \underline{\text { Vol.NaOH used }(\mathrm{mL}) \times 0,1 \mathrm{~N} \mathrm{NaOH} \times \text { miliequivalent factor } \times 100}$ mass of sample (g)
Where $\mathrm{V}$ is the volume of titrant $(\mathrm{mL}), \mathrm{F}$ is the concentration of $\mathrm{NaOH}(\mathrm{mol} / \mathrm{L}), \mathrm{M}$ is the mass of yogurt titrated $(\mathrm{g})$ and 0.9 belongs to the conversion factor of lactic acid.

Protein analysis was carried out using Sørenson formol titration, where yogurt was titrated with potassium hydroxide in the presence of formaldehyde (Levy, 1932). Lactic acid bacteria count was conducted using total plate count method. The organoleptic test was also carried out to determine its color, odor and taste. Organoleptic test using quantitative descriptive analysis (QDA). The procedure for the ginger yogurts was similar to that used by Yang et al. (2012) for peach-flavored yogurt drinks. Because semi-trained assessors have been found to be appropriate for studying major characteristics of products, we organized the panel with 10 semi-trained assessors ( 5 females and 5 males in the age range of 18-55 years). The assessors were trained in 6 sessions and for $2 \mathrm{hrs}$ each. In the first 3 sessions, they were trained for developing the vocabulary of descriptors, and in the next 2 sessions, the assessors established the references of each attribute. All 5 samples were served to the assessors in $100-\mathrm{mL}$ plastic cups with lids labeled with 3 -digit random codes and the evaluations were repeated 4 times.

\section{Results and discussion}

\section{$3.1 \mathrm{pH}$ and titratable acidity}

Effects of different ginger extract concentration on $\mathrm{pH}$ value and acidity of yogurt samples were investigated and the results were presented in Figure 1 and 2. It is seen that the time of fermentation and the level of the added ginger extract was reducing the $\mathrm{pH}$ (Figure 1) and increasing the acidity (Figure 2). The titratable acidity is expressed as a percentage of lactic acid present in the yogurt samples (Matela et al., 2019). This phenomenon as a result of the production of lactic acid by fermentative organisms responsible for the fermentation. But there was no significant difference between the lower or higher addition of ginger extract. According to Ihemeje et al. (2015), fermentation of sugars in milk (specifically lactose) into lactic acid will increase the acidity of milk and hence decreases $\mathrm{pH}$ value. This statement was also supported by Marshall (1987), who concluded that the acidic taste of yogurt was caused by lactic acid formation. Streptococcus thermophilus will first reduce the initial $\mathrm{pH}$ to less than 5.5 by synthesizing formic acid. Lactobacillus bulgaricus growth was simultaneously stimulated by formic acid and further lower the $\mathrm{pH}$ as Streptococcus thermophilus bacterial activity decreases (Bourlioux and Pochart, 1988). The acidity of yogurt samples in this study was $1.3-3.1 \%$, still within the Indonesian National Standard of $0.5-2 \%$ (SNI, 
2009).

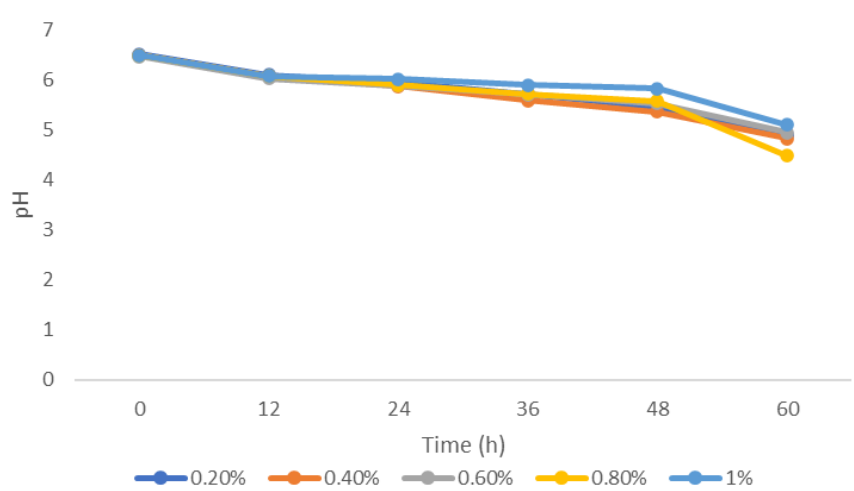

Figure 1. $\mathrm{pH}$ of yogurt with various red ginger extract concentration

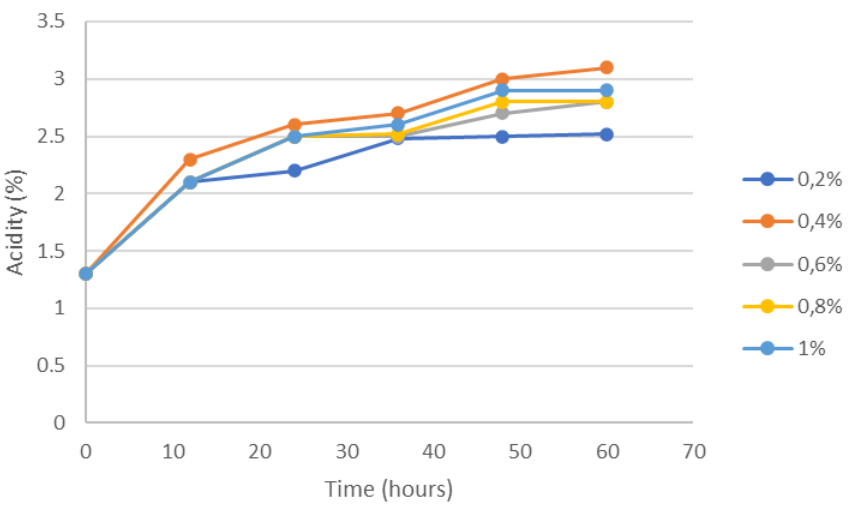

Figure 2. Titratable Acidity of yogurt with various red ginger extract concentration

\subsection{Density}

The results of this study indicate increasing fermentation time would decrease yogurt density (Figure $3)$. Bacteria's activity on yogurt production were fermented lactose (milk sugar) to lactic acid. Longer fermentation time would be increasing lactic acid formation (Turner et al., 2016). Density is the amount of mass over volume, therefore less mass would lead to less density (SERC, 2020). Increasing of lactic acid decreases density of yogurt because of its molecular weight which is the mass of a molecule of a substance. Lactic acid has a molecular weight of $90.08 \mathrm{~g} / \mathrm{mol}$ (National Center for Biotechnology Information, 2020), which was lighter

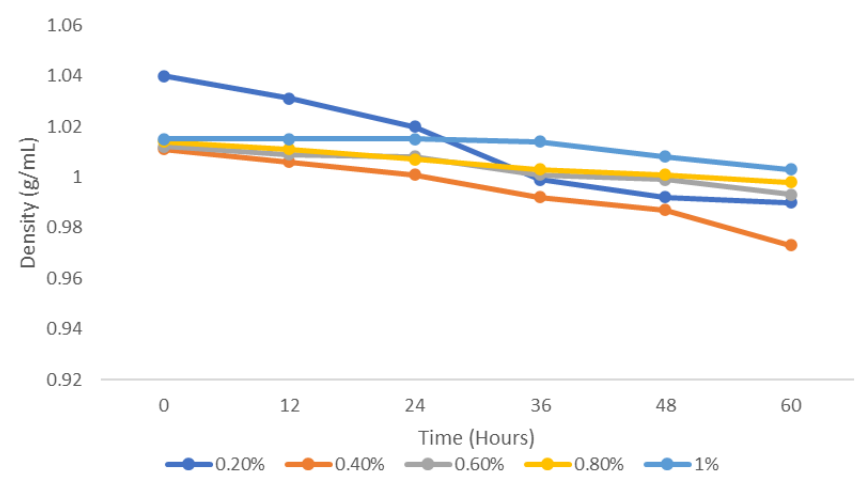

Figure 3. Density of yogurt with various red ginger extract concentration than lactose that has a molecular weight of $342.3 \mathrm{~g} / \mathrm{mol}$ (National Center for Biotechnology Information, 2020).

\subsection{Protein content}

As can be seen in Table 1, there is no significant difference in protein content in various concentration of red ginger addition. Based on the protein analysis, red ginger that use for fermentation doesn't contain protein this causes red ginger extract to yogurt did not give any significant effect to the protein content. The protein content among all concentration of red ginger extract has similar values with no clear trend(s) shown.

Table 1. Protein content of yogurt with various red ginger extract concentration

\begin{tabular}{cccccc}
\hline \multirow{2}{*}{$\begin{array}{c}\text { Time } \\
\text { (hours) }\end{array}$} & $0.20 \%$ & $0.40 \%$ & $0.60 \%$ & $0.80 \%$ & $1.00 \%$ \\
\hline 0 & 3.50 & 3.49 & 3.51 & 3.50 & 3.51 \\
12 & 3.50 & 3.49 & 3.51 & 3.50 & 3.51 \\
24 & 3.50 & 3.49 & 3.51 & 3.50 & 3.51 \\
36 & 3.49 & 3.49 & 3.51 & 3.51 & 3.51 \\
48 & 3.49 & 3.50 & 3.52 & 3.51 & 3.51 \\
60 & 3.49 & 3.50 & 3.52 & 3.51 & 3.51 \\
\hline
\end{tabular}

\subsection{Organoleptic analysis}

The yogurt produced was organoleptically tested to 10 respondents for its odor, flavor and color. Table 2 shows that scores of yogurt aroma improved with increasing the amount of ginger extract. Yogurt produced have a spicy and pungent ginger aroma, particularly in a higher concentration of red ginger extract. According to Ketaren (1987), the spicy aroma of ginger is caused by zingiberene and zingiberol, 2 essential oil compounds found in red ginger. The addition of ginger extract could take weaken effect on the sweetness but increase the spicy flavor. Red ginger has a natural spicy flavor that comes from oleoresin (Jyotsna et al., 2017). For the color of the yogurt produced, the results stated that it has a yellowish-white color, approximately of similar color to the commercial yogurt.

Table 2. Organoleptic analysis of yogurt with various red ginger extract concentration

\begin{tabular}{ccccc}
\hline \multirow{2}{*}{ Variable } & \multirow{2}{*}{ Odour } & \multirow{2}{*}{ Color } & \multicolumn{2}{c}{ Flavor } \\
\cline { 4 - 5 } & & & Sweet & Spicy \\
\hline $0.20 \%$ & 1.75 & 2.15 & 3.75 & 2.20 \\
$0.40 \%$ & 1.78 & 2.16 & 3.70 & 2.23 \\
$0.60 \%$ & 1.86 & 2.20 & 3.64 & 2.86 \\
$0.80 \%$ & 1.97 & 2.22 & 3.58 & 3.17 \\
$1.00 \%$ & 2.20 & 2.22 & 3.50 & 3.22 \\
\hline
\end{tabular}

\subsection{Lactic acid bacteria count}

Table 3 shows the results of lactic acid bacteria count $(\mathrm{LABC})$ at fermentation time $60 \mathrm{~h}$. There was an increasing bacterium count for $0.4 \% v / v$ addition of red 
ginger extract, then the bacteria count were decreased and had similar value for $0.6 \%, 0.8 \%$, and $1 \% v / v$ ginger extract addition. A study conducted by Srivastava et al. (2015) stated that red ginger has the capability to be an antimicrobial and antifungal agent. So, at higher concentrations of red ginger, the antimicrobial and antifungal characteristics began to affect the bacterial activity.

Table 3. Lactic acid bacteria count of yogurt with various red ginger extract concentration at $60 \mathrm{hrs}$ fermentation

\begin{tabular}{cc}
\hline Variable & Total BAL $(\mathrm{CFU} / \mathrm{mL})$ \\
\hline $0.00 \%$ & $1.8 \times 10^{9}$ \\
$0.20 \%$ & $1.8 \times 10^{9}$ \\
$0.40 \%$ & $2.3 \times 10^{9}$ \\
$0.60 \%$ & $1.8 \times 10^{9}$ \\
$0.80 \%$ & $1.8 \times 10^{9}$ \\
$1.00 \%$ & $1.8 \times 10^{9}$ \\
\hline
\end{tabular}

\section{Conclusion}

$\mathrm{pH}$ of yogurt was decreasing and titratable acidity increased during the fermentation time in various concentration of ginger extract addition. The addition of red ginger extract did not give a significant effect on protein content of yogurt. Yogurt with a higher concentration of ginger extract increased the spicy aroma and flavor, however, the color was similar to the commercial yogurt. At higher concentrations of red ginger shows antimicrobial and antifungal characteristics, so there's no increase in microorganisms' amount.

\section{Conflict of interest}

The authors declare no conflict of interest.

\section{Acknowledgments}

The research work was funded by Penelitian Strategis Nasional Institusi, Directorate General of Higher Education, Ministry of National Education Indonesia (Grant no. 101-177/UN7.P4.3/PP/2018). We also thank Prof. Dr. Iswardi Jaswir (INHART IIUM, Malaysia) for his correction contribution in this work.

\section{References}

Abubakar, A., Saito, T., Kitazawa, H., Kawai, Y. and Itoh, T. (1998). Structural analysis of new antihypertensive peptides derived from cheese whey protein by proteinase K digestion. Journal Dairy Science, 81, 3131-3138. https://doi.org/10.3168/ jds.S0022-0302(98)75878-3

Adolfsson, O., Meydani, S.N. and Russell, R.M. (2004). Yogurt and gut function. American Journal Clinical
Nutrition, 80(2), 245-256. https://doi.org/10.1093/ ajcn/80.2.245

Amadou, N.M., Richard, E.A., Jules-Roger, K., Waingeh, N.C., Ateh, K.D., Mbiydzengeh, A.F., Che, N.S. and Yunenyui, M.P. (2018). Effect of ginger extract on the physicochemical and sensory properties of yogurt. International Journal of Development Research, 8(5), 20468-20477.

Baba, W.N., Jan, K.P., Hilal, A.P., Wani, T.A., Dar, M. and Masoodi, F.A. (2018). Techno-functional properties of yogurts fortified with walnut and flaxseed oil emulsions in guar gum. LWT - Food Science and Technology, 92(1), 242-249. https:// doi.org/10.1016/j.lwt.2018.02.007

Bourlioux, P. and Pochart, P. (1988). Nutritional and health properties of yogurt. World Review of Nutrition and Dietetics, 56, 217-218. https:// doi.org/10.1159/000416229

Buttris, J. (1997). Nutritional properties of fermented milk products. International Journal of Dairy Technology, 50, 21-27. https:// doi.org/10.1159/000416229

Fernandez, M.A. and Marette, A. (2017). Potential Health Benefits of Combining Yogurt and Fruits Based on Their Probiotic and Prebiotic Properties. Advances in Nutrition Journal, 8(1), 155-164. https://doi.org/10.3945/an.115.011114

Heymans, M. (2000). Effect of lactic acid bacteria on diarrheal diseases. Journal of The American College of Nutrition, 19, 137-146. https:// doi.org/10.1080/07315724.2000.10718084

Ihemeje, A., Nwachukwu, C.N. and Ekwe, C.C. (2015). Production and quality evaluation of flavored yogurts using carrot, pineapple and spiced yogurts using ginger and pepper fruit. African Journal of Food Science, 9(3), 163-169. https://doi.org/10.5897/ AJFS2014.1244

Jyotsna, D., Neelam, A. and Viveka, N. (2017). A review on Zingiber officinale. Journal of Pharmacognosy and Phytochemistry, 6(3), 174-184.

Ketaren, S. (1987). Pengantar Teknologi Minyak Atsiri. $1^{\text {st }}$ ed. Jakarta: Balai Pustaka. [In Bahasa Indonesia].

Krisnaningsih, A.T., Purwadi, Evanuarini, H. and Rosyidi, D. (2019). The Effect of Incubation Time to The Physicochemical and Microbial Properties of Yoghurt with Local Taro (Colocasia esculenta (L.) Schott) Starch as Stabilizer. Food and Nutrition Journal, 7(2), 547-554. https://doi.org/10.12944/ CRNFSJ.7.2.23

Leblanc, A.D.M.D. and Pedrigon, G. (2004). Yogurt feeding inhibits promotion and progression of cancer. Medical Science Monitor, 10(4), 96-104. 
Levy, M. (1932). Equilibria in The Formol Titration. New York: Department of Chemistry, New York University and Bellevue Hospital Medical College

Marshall, V.M. (1987). Fermented milk and their future trends I microbiological aspects. Journal of Dairy Research, 54, 559-574. https://doi.org/10.1017/ S0022029900025760

Matela, K.S., Pillai, M.K. and Thamae, T. (2019). Evaluation of $\mathrm{pH}$, titratable acidity, syneresis and sensory profiles of some yoghurt samples from the Kingdom of Lesotho. Food Research Journal, 3(6), 693-697. https://doi.org/10.26656/fr.2017.3(6).177

National Center for Biotechnology Information. (2020). PubChem Database, beta-Lactose. Retrieved on March 18, 2020 from https:// pubchem.ncbi.nlm.nih.gov/compound/beta-Lactose.

Perdigeon, G., Valdez, J. and Rachid, M. (1998). Antitumor activity of yogurt: study of possible immune response. Journal of Dairy Research, 65(1), 129-138. https://doi.org/10.1017/ S0022029997002604

Science Education Resource Center at Carleton College (SERC). (2020). Density and Specific Gravity in Geosciences. Retrieved on March 18, 2020 from https://serc.carleton.edu/mathyouneed/density/ind ex.htmL.

Srivastava, P., Prasad, S.G.M., Ali, M.N. and Prasad, M. (2015). Analysis of antioxidant activity of herbal yogurt prepared from different milk. The Pharma Innovation Journal, 4(3), 18-20.

Rajathi, A.A., Sundarraj, A.A., Leslie, S. and Pragalyaashree, M.M. (2017). Processing and medicinal uses of cardamom and ginger - a review. Journal of Pharmaceutical Sciences and Research, 9 (11), 2117-2122.

Tajkarimi, M.M., Ibrahim, S.A. and Cliver, D.O. (2010). Antimicrobial herb and spice compounds in food. Food Control, 21(9), 1199-1218. https:// doi.org/10.1016/j.foodcont.2010.02.003

Tamime, A.Y. and Marshall, V.M.E. (1997). Microbiology and Technology of Fermented Milks. In Law, B.A. (Ed). Microbiology and Biochemistry of Cheese and Fermented Milk, p. 57-192. USA: Springer. https://doi.org/10.1007/978-1-4613-1121$8 \_3$

Turner, T.L., Zhang, G., Kim, S.R., Subramaniam, V., Steffen, D.M., Skory, C.D., Jang, J.Y., Yu, B.J. and Jin, Y.S. (2015). Lactic Acid Production from Xylose by Engineered Saccharomyces cerevisiae without PDC or ADH Deletion. Journal of Applied Microbiology and Biotechnology, 99(19), 80238033. https://doi.org/10.1007/s00253-015-6701-3
Yang, G.H., Guan, J.J., Wang, J.S., Yin, H.C., Qiao, F.D. and Jia, F. (2012). Physicochemical and Sensory Characterization of Ginger-Juice Yogurt during Fermentation. Journal of Food Science Biotechnology, 21(6), 1541-1548. https:// doi.org/10.1007/s10068-012-0205-z 